\title{
The medicine selection process in four large university hospitals in Brazil: Does the DTC have a role?
}

\author{
Elisangela da Costa Lima-Dellamora ${ }^{1,2, *}$, Rosangela Caetano ${ }^{3}$, \\ Claudia Garcia Serpa Osorio-de-Castro ${ }^{2}$
}

\author{
${ }^{1}$ School of Pharmacy, Federal University of Rio de Janeiro, Brazil, ${ }^{2}$ Sergio Arouca National School of Public Health, \\ Post-Graduate Program, Oswaldo Cruz Foundation, Rio de Janeiro, Brazil, ${ }^{3}$ Social Medicine Institute, \\ State University of Rio de Janeiro, Rio de Janeiro, Brazil
}

\begin{abstract}
Knowledge about evidence-based medicine selection and the role of the Drug and Therapeutics Committee (DTC) is an important topic in the literature but is scarcely discussed in Brazil. Our objective, using a qualitative design, was to analyze the medicine selection process performed in four large university hospitals in the state of Rio de Janeiro. Information was collected from documents, interviews with key informants and direct observations. Two dimensions were analyzed: the structural and organizational aspects of the selection process and the criteria and methods used in medicine selection. The findings showed that the DTC was active in two hospitals. The structure for decision-making was weak. DTC members had little experience in evidence-based selection, and their everyday functions did not influence their participation in DTC activities. The methods used to evaluate evidence were inadequate. The uncritical adoption of new medicines in these complex hospital facilities may be hampering pharmaceutical services, with consequences for the entire health system. Although the qualitative approach considerably limits the extent to which the results can be extrapolated, we believe that our findings may be relevant to other university hospitals in the country.
\end{abstract}

Uniterms: Medicines/selection. Drug and Therapeutic Committees. University hospitals/medicines selection.

A produção de conhecimento sobre a seleção de medicamentos baseada em evidências e executada por Comissões de Farmácia e Terapêutica é ainda escassa no Brasil, apesar da ampla discussão sobre o tema em países desenvolvidos. Este estudo buscou conhecer e analisar os aspectos relacionados à seleção de medicamentos em quatro hospitais universitários de grande porte no Rio de Janeiro, por meio de abordagem qualitativa. Entrevistas, observação direta e análise documental instrumentaram a coleta de dados qualitativos e quantitativos. A análise considerou duas dimensões: (i) estrutura e organização para o processo de seleção e (ii) critérios e métodos utilizados para avaliação. Apenas dois hospitais possuíam Comissão de Farmácia e Terapêutica (CFT) ativa. A estrutura para a tomada de decisão era deficiente e os membros das Comissões apontaram pouca experiência e disponibilidade para a atividade. Os métodos de avaliação e critérios observados indicaram um processo de seleção acrítico nestes hospitais, comprometendo a assistência farmacêutica e potencialmente prejudicando o sistema de saúde. Apesar da metodologia qualitativa não permitir a extrapolação de resultados, é possível que este cenário seja parecido com o de outros hospitais universitários brasileiros.

Unitermos: Medicamentos/seleção para uso. Comissão de Farmácia e Terapêutica. Hospitais universitários/seleção de medicamentos.

\footnotetext{
*Correspondence: Elisangela da Costa Lima-Dellamora. Faculdade de Farmácia, Universidade Federal do Rio de Janeiro. Avenida Carlos Chagas Filho, 373 - Bloco L, subsolo, sala 28, Cidade Universitária, 21.941-902 - Rio de Janeiro, RJ - Brasil. E-mail: lima.dellamora@gmail.com
} 


\section{INTRODUCTION}

The rational use of health technologies - medicines, equipment and devices, medical and surgical procedures, organization and support systems (Brasil, 2010) - implies that their selection must be satisfactory to justify financing decisions and also requires the identification of the conditions in which they must be used (Krauss-Silva, 2003). Clinical, social and economic impacts should be considered in terms of analyses of efficacy, safety and comparative cost-effectiveness. In the case of medicines, the World Health Organization states that activities linked to the selection process must be performed, either in institutions or in health systems, by the Drug and Therapeutics Committee (DTC), with the participation of health professionals with expertise in the assessment of scientific evidence (WHO, 2003).

The DTC must have clear goals, a firm mandate, support from institutional management or government, transparency in its procedures, wide representation, technical competence, multidisciplinary focus and sufficient resources to implement its decisions (WHO, 2003).

These Committees have several functions. Their main roles involve the evaluation and selection of medicines and the development hospital wise use of medicines policies, including guidelines and therapeutic monitoring (WHO, 2003). DTC activities are well established in most European countries, the USA, Canada and Australia. In Brazil, these committees are non-mandatory, and their implementation has not been forthcoming (Marques, Zucchi, 2006; Veber et al., 2011). A 2003 national assessment showed that a mere $29(11 \%)$ of 250 investigated hospitals presented nominal DTCs, but operational DTCs were seen in only $3.6 \%$ of hospitals (Osorio-de-Castro, Castilho, 2004).

University hospitals have a central role in highly complex health care. Due to this profile, they tend to adopt new technologies (Medici, 2001). Theoretically, they are an adequate setting for health technology assessment and DTC membership. Clinical decision makers participating in the education of other health professionals and other stakeholders involved in health innovation are present in this setting.

Because the adoption of new technologies has very important clinical and financial impact for patients, health institutions and systems, it is relevant to understand the selection process in greater depth. This process determines the technologies that will eventually be acquired and used. In terms of the adoption of new technologies, this generalization is especially true for tertiary Brazilian university hospitals, which are perceived as playing a leadership role in the health system and where intense pharmaceutical marketing practices are ongoing (Palácios, Rego, Lino, 2008).

The principal trend-setters are hospitals located in the more developed Brazilian Southeast. These services are viewed as a gateway for the entire health system in terms of the adoption of new technologies. This study aims to analyze the medicine selection process in four tertiary university hospitals in the state of Rio de Janeiro.

\section{METHODOLOGY}

A multiple case study was conducted (Yin, 2005). The research involved the collection and analysis of quantitative and qualitative data, with the objective of understanding the role of the DTCs (if present), the alternative selection process (if no DTC existed), the perspectives of the actors involved and other underlying aspects related to the selection of medicines in these hospitals.

Brazil has 39 tertiary university hospitals characterized by (a) a highly complex care profile, (b) the presence of multiple medical specialties and (c) a clinical body composed primarily of professors (Medici, 2001; Portela et al., 2004). Fifteen of these hospitals are in the Southeast. All tertiary university hospitals in the State of Rio de Janeiro were selected for study because of their geographical proximity and because of the size of the State's population (16 million people) (Brasil, 2011; Abrahue, 2012; IBGE, 2012).

A reference matrix organized in dimensions - (i) structure and organization of the selection process and (ii) criteria and methods adopted - guided the collection, data analysis and presentation of results. This matrix was based on WHO recommendations on the evaluation and selection of medicines, on experiences in several countries (USA, Canada, United Kingdom, England, Spain, Denmark, Laos, Australia, Nepal, Sweden, Holland, Germany) reported in the scientific literature and on a national Brazilian gold standard institution (Lima-Dellamora et al., 2014).

A pilot study in a specialized 114-bed public teaching hospital was conducted to improve data collection instruments and procedures. A total of 27 visits were made to the selected hospitals between January and June, 2011. Data collection was accomplished through (i) document search, (ii) semi-structured interviews with key stakeholders and (iii) direct observation.

Information from hospital documents included description of the health care profile and details pertaining 
to the medicine selection process, such as an essential medicines list (EML); minutes of the DTC meetings; forms for requesting inclusion of medicines in the EML; requests for purchase of non-formulary medicines; forms or other documents related to medicines donations or medicines involved in clinical research; and other documents such as ordinances, statutes, internal communications, reports, studies or drug use evaluations and hospital pharmacy records.

The interviews were performed with 17 key stakeholders involved in the medicine selection process, such as hospital managers (general director and/or clinical director), heads of hospital pharmacy services and DTC members. All signed an informed consent form.

Direct observation of the DTC meetings was important in understanding the subtleties of the environment and the workings of the selection process. All information on (a) the structure and organization used for selection, (b) membership and participation criteria, (c) roles and responsibilities, (d) criteria, and (e) methods used throughout the drug evaluation process was recorded in a field journal, facilitating comparisons with information in documents and interviews.

The analysis was preceded by a thorough organization of information based on dimensions (hereafter termed categories) in the reference framework. The interviews were analyzed based on content analysis, first by identification of a set of central nuclei (Bardin, 2002) and subsequently organized in the pre-established categories and compared to the framework (LimaDellamora et al., 2014).

The project was approved by the National Public Health School Ethics in Research Committee.

\section{RESULTS}

The four hospitals selected were coded as A, B, $\mathrm{C}$ and $\mathrm{D}$ to make their identification more difficult. The number of beds varied from 186 to 466 (Table I). All facilities had wards for highly complex care in Oncology, Nephrology, Neurology, Critical Care and Orthopedics. Three hospitals offered transplant services.

The ratio between the number of physicians and the number of beds was relatively homogeneous - between 2 (hospital D) and 2.76 (hospital C) - whereas the total number of health professionals per bed varied from 3.55 (hospital C) to 7.67 (hospital D).

The DTC was cited as responsible for the process of selecting medicines in hospitals A, B and C but was official only in A and B (Table II). In hospital C, the DTC activities had been suspended, as mentioned by one of the interviewees:

The DTC selected [the medicines]. But this routine was subverted; (...) the DTC has stopped its ac-

TABLE I - Care profile of large, highly complex university hospitals. State of Rio de Janeiro, 2011

\begin{tabular}{|c|c|c|c|c|c|}
\hline \multirow{2}{*}{ PROFILE } & & \multicolumn{4}{|c|}{ HOSPITALS } \\
\hline & & $\mathrm{A}$ & $\mathrm{B}$ & $\mathrm{C}$ & $\mathrm{D}$ \\
\hline \multicolumn{2}{|l|}{ Patient flow } & $\begin{array}{c}\text { Reference and } \\
\text { Counter-reference }\end{array}$ & $\begin{array}{c}\text { Spontaneous } \\
\text { Demand + Reference } \\
\text { and Counter- } \\
\text { reference }\end{array}$ & $\begin{array}{c}\text { Reference and } \\
\text { Counter-reference }\end{array}$ & $\begin{array}{c}\text { Spontaneous } \\
\text { Demand + Reference } \\
\text { and Counter- } \\
\text { reference }\end{array}$ \\
\hline Health Insurance & & SUS* & SUS & $\begin{array}{c}\text { Private Insurance, } \\
\text { SUS }\end{array}$ & SUS \\
\hline \multirow{4}{*}{ Beds } & Surgery & 114 & 85 & 175 & 188 \\
\hline & Intensive Care & 31 & 18 & 35 & 69 \\
\hline & Other & 107 & 83 & 232 & 209 \\
\hline & Total & 252 & 186 & 442 & 466 \\
\hline \multirow{3}{*}{ Hospital staff } & Physicians & 607 & 443 & 1221 & 940 \\
\hline & $\begin{array}{l}\text { Other Health } \\
\text { Professionals }\end{array}$ & 689 & 516 & 349 & 2636 \\
\hline & Total & 1296 & 959 & 1570 & 3576 \\
\hline $\begin{array}{l}\text { Facilities (rooms and } \\
\text { offices) }\end{array}$ & & 100 & 141 & 102 & 289 \\
\hline
\end{tabular}

*SUS: Sistema Único de Saúde (Brazil's Unified Health System). Source: Brasil, 2011. 
TABLE II - Responsibilities pertaining to medicine selection in university hospitals. State of Rio de Janeiro, 2011

\begin{tabular}{|c|c|c|c|c|}
\hline \multirow{2}{*}{ ASPECTS } & \multicolumn{4}{|c|}{ HOSPITALS } \\
\hline & $\mathbf{A}$ & B & $\mathbf{C}$ & $\mathbf{D}$ \\
\hline Responsible entity & DTC & DTC & DTC & $\begin{array}{l}\text { Pharmacy / Technical } \\
\text { Services Coordination }\end{array}$ \\
\hline $\begin{array}{l}\text { Ordinance constituting } \\
\text { DTC }\end{array}$ & Yes & Yes & No & No \\
\hline $\begin{array}{l}\begin{array}{l}\text { Frequency of DTC } \\
\text { meetings }\end{array} \\
\end{array}$ & $\begin{array}{c}\text { Non-regular monthly } \\
\text { meetings }\end{array}$ & $\begin{array}{l}\text { Regular monthly } \\
\text { meetings }\end{array}$ & $\begin{array}{c}\text { Meetings temporarily } \\
\text { suspended }\end{array}$ & Meetings nonexistent \\
\hline $\begin{array}{l}\text { Available DTC } \\
\text { documentation (year) }\end{array}$ & $\begin{array}{c}\text { Pharmacy Manual } \\
(2010) \\
\text { Service } \\
\text { Communication } \\
(2008,2011) \\
\text { DTC Minutes of } \\
\text { Meetings (2010-2011) } \\
\text { Medicine Inclusion } \\
\text { Forms (2010-2011) } \\
\text { Medicine Request } \\
\text { Documents (2010- } \\
2011) \\
\text { Opinion about } \\
\text { Inclusion Requests } \\
(2010) \\
\text { Medicine Inclusion } \\
\text { Request Protocol } \\
\text { (2010) }\end{array}$ & $\begin{array}{c}\text { Essential Medicines } \\
\text { List (2010) } \\
\text { DTC Internal } \\
\text { Regiment (2010) } \\
\text { DTC Members } \\
\text { Indication Ordinance } \\
\text { (2010) } \\
\text { DTC Minutes of } \\
\text { Meetings (2010-2011) } \\
\text { Medicines Inclusion } \\
\text { Forms (2010-2011) } \\
\text { Non-Standard } \\
\text { Medicines Requests } \\
\text { (2011) }\end{array}$ & $\begin{array}{c}\text { DTC Members } \\
\text { Indication Ordinance } \\
(2008,2010) \\
\text { DTC Minutes of } \\
\text { Meetings (2008 } \\
-2010) \\
\text { Medicines } \\
\text { Procurement Service } \\
\text { Orders (2009-2011) } \\
\text { Internal } \\
\text { Communications } \\
\text { about Medicines } \\
\text { Procurement and } \\
\text { Standardization (2009 } \\
\text {-2011) } \\
\text { Medicines Inclusion } \\
\text { Requests (2008-2009) } \\
\text { DTC Bylaw (2003) }\end{array}$ & $\begin{array}{c}\text { Medicines } \\
\text { Procurement Requests } \\
(2011) \\
\text { Internal } \\
\text { Communications } \\
\text { about Medicines } \\
\text { Procurement (2011) } \\
\text { Medicines Inclusion } \\
\text { Requests (2011) }\end{array}$ \\
\hline
\end{tabular}

tivities. [As in the case of] clopidogrel: Cardiology requested it and Management suffered pressure to adopt it without any kind of evaluation (Interviewee 13).

In Hospital D, Pharmacy Services Management was responsible for decisions on medicine selection.

The Pharmacy selects the medicines. But it's confusing; [actually] there are several other ways in which medicines are adopted here (Interviewee 17).

\section{Structural and organizational aspects of the selection process}

The results are presented in Table 3 (DTC structure and membership) and Table 4 (DTC functions). Important limitations were observed regarding DTC organization in cases in which this committee was present. In hospital $\mathrm{D}$, information about the organization of the selection process within the Hospital Pharmacy was sought but was nonexistent (Table III).

In hospitals A and B, DTC meetings were held in the Board Room, which appeared to make activities more difficult due to a work environment that did not meet the needs of the DTC:

We lack a meeting room, equipment, a computer (...). So, it's tough (Interviewee 9).

The DTCs of hospitals A and B had up-to-date statutes and procedures. In these same hospitals, there had been at least one DTC meeting within the six-month data collection period. Hospital management followed up activities. When questioned, however, managers did not produce even rough estimates of the yearly expenditures on medicines.

The DTCs of hospitals A and B had, on average, eight members, including doctors, nurses and pharmacists. Professors or department heads of Internal Medicine, Surgery, Oncology and Infectious Diseases (or the Hospital Infection Control Committee) usually represented the medical specialties. The Committees had no clinical pharmacologists.

All members, without exception, mentioned the inability to reconcile their work routines and DTC demands. The members prioritized other activities, indicating this as one of their main difficulties: 
The committee demands more time than I have to offer. This is a constant problem for everyone. We meet very seldom, even when there is an external demand (Interviewee 3)
Could we have prepared all the guidelines? Yes, but, for that, we'd have to have more time, more availability (Interviewee 8).

TABLE III - Structure and organization of DTCs (or other) related to medicine selections in university hospitals. State of Rio de Janeiro, 2011

\begin{tabular}{lccccc}
\hline STRUCTURE AND & \multicolumn{5}{c}{ HOSPITALS } \\
\cline { 2 - 6 } ORGANIZATION & A & B & C & D $^{*}$ \\
FOR SELECTION & & A & & & \\
\hline
\end{tabular}

Technical and administrative support for DTC (office space, human resources, access to databases)

\begin{tabular}{|c|c|c|c|c|}
\hline $\begin{array}{l}\text { for DTC (office space, } \\
\text { human resources, access } \\
\text { to databases) }\end{array}$ & $\begin{array}{c}\text { Non-exclusive } \\
\text { secretary support }\end{array}$ & No support & No support & No DTC \\
\hline
\end{tabular}

Support and monitoring of activities by hospital board or medical board (MB)

\section{Non-exclusive}

Direct participation of $\mathrm{MB}$ as

DTC member.
No support

No DTC

\section{Proposals and}

alternatives to distance committee members from potential conflicts of interest

\begin{tabular}{|c|c|c|c|c|}
\hline Committee membership & $\begin{array}{l}\text { MB (president), } \\
\text { representation } \\
\text { by sector: IHC, } \\
\text { Cardiology, } \\
\text { Hematology, } \\
\text { Anesthesiology, } \\
\text { Pharmacy and } \\
\text { ICC according to } \\
\text { ordinance. } \\
\text { No definition of } \\
\text { working hours or } \\
\text { members' terms. }\end{array}$ & $\begin{array}{l}\text { MB, representation } \\
\text { by clinic/service: } \\
\text { General Surgery } \\
\text { (president), Oncology, } \\
\text { Hematology, } \\
\text { Pharmacy and Nurse. } \\
\text { No definition of } \\
\text { working hours and } \\
\text { members' terms. }\end{array}$ & $\begin{array}{c}\text { No assignment during } \\
\text { this study. } \\
\text { No definition of } \\
\text { working hours or } \\
\text { members' terms. }\end{array}$ & No DTC \\
\hline Participation criteria & $\begin{array}{c}\text { Sector Heads } \\
\text { and pharmacist } \\
\text { indicated by Hospital } \\
\text { Pharmacy; } \\
\text { (public servants only). }\end{array}$ & $\begin{array}{c}\text { Medical specialists } \\
\text { and Pharmacy Head } \\
\text { representation. } \\
\text { (public servants only). }\end{array}$ & $\begin{array}{c}\text { Medical specialists } \\
\text { and Pharmacy Head } \\
\text { representation. } \\
\text { (interns, residents and } \\
\text { public servants). }\end{array}$ & No DTC \\
\hline $\begin{array}{l}\text { Presence of ad hoc } \\
\text { consultants }\end{array}$ & $\begin{array}{l}\text { No definition } \\
\text { in the bylaw. }\end{array}$ & $\begin{array}{l}\text { No definition in the } \\
\text { bylaw. }\end{array}$ & $\begin{array}{l}\text { No definition } \\
\text { in the bylaw. }\end{array}$ & No DTC \\
\hline
\end{tabular}

MB: Medical Board, IHC: Intensive Health Care; ICC: Infection Control Committee, EML: Essential Medicines List. 
Membership requirements ignored the minimum criteria regarding members' theoretical knowledge of medicine selection or experience in evidence-based evaluation:

I got into this committee out of the blue (Interviewee 8).

I became a member and, you know, it's not necessarily because you fit the profile. There is no one else, so you have to go, to ensure the representation (Interviewee 9).

Further difficulties regarded unjustified member absenteeism and vacations taken by individual members or by a majority of the group at the same time. At hospital $\mathrm{C}$, documents sent to the hospital management by the DTC president, transmitted the previous year, brought complaints to light regarding the lack of members' participation in meetings.

In the rules or statutes of the DTCs of hospitals A, $\mathrm{B}$ and $\mathrm{C}$, the collaboration of specialists and researchers, both internal and external ( $a d$ hoc), was not foreseen. In none of the hospitals was the use of strategies for controlling possible conflicts of interest regarding medicines mentioned by any of the interviewees.

Only hospital A appeared to perform most of the functions foreseen for the DTC (Table IV). In hospital $\mathrm{C}$, medicines use policies that had been developed in the past were not followed. In hospitals B and D, definitions of therapeutic protocols and guidelines and of medicines use policies had not been established.

None of the DTCs aided the health care staff regarding information on medicines.

\section{Criteria and methods used in medicine selection}

The inclusion of medicines in the EML was limited to discussions, with little depth regarding the arguments presented by the applicant. In hospitals A and B, selection criteria were, at least, mentioned in the DTC statutes. One of the DTC members in hospital B reinforced the feeling that the implementation of selection criteria in the institution was conducted only superficially.

We do as follows: we have a list of medicines. If the patient has a disease and the drug for it is listed, we accept the patient. If we don't have the drug, we say that the drug of choice is not in the hospital's EML [and turn the patient away], see? (Interviewee 11).

No methods were observed for comparisons of benefits and risks between the medicines suggested for inclusion in the EML and those already on the list. The only pre-existing condition for the request to be accepted for analysis was that it be accompanied by some type of literature:

(...) at the moment when an application for inclusion shows up, if it is accompanied by literature, the tendency is to approve [it](...) This new drug, due to the cost, may not be available at all times, but we do include it (Interviewee 8).

In hospital A, the evaluation of inclusion requests by the DTC would occur only after an evaluation feedback made by one of its members. However, the reviewer's evaluation was always accepted without any debate by the other members. The requests submitted by DTC members were not passed on to reviewers. The medicine's inclusion in the EML was automatic and became official at the following meeting.

In hospital B, neither analysis of inclusion requests by members nor a standardized review form were planned as minimum requirements in the evaluation process.

(...) when we are analyzing a scientific paper, we must have someone to draft the main results and show it to us. (...) the members don't have time for that (...) it ends up as a task of the applicant, and he (or she) will give you the information (Interviewee 11).

The analysis of evidence never included the investigation of the quality of evidence (i.e., sample size and methodology, internal validity) or external validity of the studies. One of the interviewees noted that these analyses would not be feasible in Brazilian hospitals:

This is all very nice, but it's not for us, OK? It's not for Brazil. No one in this country can manage what the WHO recommends. (Interviewee 12)

The lack of organization and method in the evaluation process result in the insecurity of members when they are confronted with the need to make a selection decision:

I can tell you there is no script, no dynamics for the evaluation (...) I felt unprepared for positioning myself strongly (Interviewee 13).

In hospitals $\mathrm{C}$ and $\mathrm{D}$, medicine selection was based on written demands for the purchase of certain drugs, either as prescriptions or signed requests sent to the Pharmacy Service:

The doctor makes a written request for the purchase of a non-standard medication. But if they begin asking for too much of the same medication, I decide to include it in the list (...) I don't have time to research anything. [What I do is] I look at the price. If it's 
TABLE IV - Functions related to medicine selection in university hospitals. State of Rio de Janeiro, 2011

\begin{tabular}{|c|c|c|c|c|}
\hline \multirow{2}{*}{$\begin{array}{l}\text { DTC ROLES AND } \\
\text { RESPONSIBILITIES }\end{array}$} & \multicolumn{4}{|c|}{ HOSPITALS } \\
\hline & $\mathbf{A}$ & B & $\mathbf{C}$ & D \\
\hline $\begin{array}{l}\text { Assessment and } \\
\text { selection of medicines }\end{array}$ & $\begin{array}{l}\text { No monthly regularity. } \\
\text { Poor evaluation. }\end{array}$ & $\begin{array}{l}\text { Monthly meetings. } \\
\text { Poor evaluation. }\end{array}$ & $\begin{array}{l}\text { Suspended during the } \\
\text { period of this study. }\end{array}$ & Not done \\
\hline $\begin{array}{l}\text { Drafting of list as final } \\
\text { product of medicine } \\
\text { selection }\end{array}$ & Yes & Yes & Not done & Not done \\
\hline $\begin{array}{l}\text { Developing drug use } \\
\text { policies }\end{array}$ & $\begin{array}{l}\text { Only defined for anti- } \\
\text { infectives or for special } \\
\text { unlisted under-protocol } \\
\text { medicines }\end{array}$ & Not done & Defined but not followed. & Not done \\
\hline $\begin{array}{l}\text { Developing and } \\
\text { monitoring therapeutic } \\
\text { guidelines }\end{array}$ & $\begin{array}{l}\text { Related to the use of } \\
\text { anti-infectives by the } \\
\text { HIC. }\end{array}$ & Not done & Not done & Not done \\
\hline $\begin{array}{l}\text { Dissemination of } \\
\text { information on medicines } \\
\text { to hospital clinical board }\end{array}$ & Not done & Not done & Not done & Not done \\
\hline
\end{tabular}

expensive, I don't decide it on my own, I send the request to my boss (Interviewee 17).

\section{DISCUSSION}

The selection of essential medicines represents one of the most important institutional policies for the rational use of medicines in health services (WHO, 2002). Observed together, other pharmaceutical services - forecasting, procurement, stockage, distribution, drug utilization (prescribing, dispensing and use) - are based on the list produced by the selection process. The critical, independent, comparative and transparent evaluation of the available options must precede decision-making. The process reaches its goal with the selection of efficient, safe technologies for the profile of the population under care (Gustafsson et al., 2011). However, meeting these criteria demands the structuring of DTCs that are aware of and committed to this crucial activity.

In the four large university hospitals that were studied, several common barriers were found: (i) very poor structural conditions and limited resources for the work of the DTC, (ii) nonexistence of participation criteria for the DTC members, (iii) very limited availability of the members for DTC functions and lack of regular attendance at meetings, (iv) little knowledge or understanding by DTC members about their functions in the evaluation process, (v) lack of expertise by members for performing all DTC functions and (vi) superficial monitoring of the DTC activities by the hospital managements.

Recent studies (Marinho, 2003; Azevedo, Fernandes, Carreteiro, 2007; Bittencourt, Hortale, 2007) have highlighted grave problems related to the management, quality and efficiency of the care of patients hospitalized in the state of Rio de Janeiro. The precarious structures of the hospital DTCs indicate that the context in these large complex-care hospitals is very similar but certainly more serious given their nature as centers for specialized care.

The actual conditions of the medicine selection process in all four hospitals, made clear by the statements of the stakeholders, reinforce the dire situation of the DTCs in these university hospitals, mainly because the minimum requirements for DTCs have been discussed throughout the world for more than 30 years (Lima et al., 2010). One of the first documents on the selection of medicines in Brazil was developed by the Ministry of Education, under which university hospitals are organized. This 1986 document discussed the implementation of DTCs in university hospitals. This fact is paradoxical and worrisome: in 27 years, highly complex care evolved, intense adoption of health technologies occurred, but little has changed in these hospitals.

The decadent infrastructure of Brazilian university hospitals is one of the most acute expressions of the crisis these institutions have experienced over the years (Guimarães, 2004). Discussing the bases for a national health, science and technology and innovation policy, 
Guimarães (2004) mentions the asymmetry between health benefits and costs and the speed at which health knowledge produced for the benefit of the population is appropriated. Another aspect of this crisis is the decrease in working hours of the best professionals in the hospital. This issue relates to DTC membership in the hospitals. Meeting attendance by members must be a requirement for the renewal of the member mandate in the DTC (WHO, 2003).

Stakeholders' perceptions regarding their role in the DTC indicates insufficient knowledge about committee functions. Without organized planning and monitoring of the selection process of new therapeutic options, absolute inertia by managers may be observed, and rational drug use is abandoned altogether.

A study on individual lawsuits demanding medicines in the State of Rio de Janeiro observed that in 2006, $22 \%$ of the Brazilian Health System (SUS) medical prescriptions present in lawsuits originated in university hospitals (Sant'ana et al., 2011). This access strategy may be justified if needed medicines are not available in the system or if there has been tardiness in adoption. Nevertheless, health litigation may also promote the unwise or hasty adoption of new technologies of doubtful efficacy or untoward harmful effects of those without an established safety profile. This scenario allows for greater expenses and ineffectiveness of health care while making institutions more prone to the pharmaceutical industry's marketing interests (Chieffi, Barata, 2010). As the results of this study showed, many stakeholders do not have the necessary skills to counter industry influence or the will to participate more fully in DTC functions, which could help prepare them for an adequate selection process. Moreover, no conflict of interest policies were observed for these committees, making members easy targets for undue influences.

During the analysis, we observed that the DTCs showed a vicious cycle of implementation. As hospital management teams changed over the years, all institutional policies regarding the use of medicines were constantly rebuilt and lost repeatedly. Some memory of past achievements existed in two hospitals, linked to members from the pharmacy services, but there had been no critical appraisal of these achievements.

The interviewees mentioned efficacy, safety and cost as criteria for selection. Comparative, user profilesensitive, needs- and evidence-based evaluation of medicines should have been the basis for the selection process (WHO, 2003). However, we observed that the DTC members were, in fact, exempting themselves from an in-depth analysis of the selection criteria, favoring, instead, political relations in the hospital as a 'substitute' criterion. The power behind the decision-making process on the adoption of health technologies in hospitals has been referred to in the literature, and university hospitals are the sites at which power struggles are prone to have consequences that may reflect on the health system as a whole (Cecilio, 1999; Medici 2001).

Even if the 'power-based' decision-making process was not primarily sensitive to need, it was very sensitive to the cost of the drugs to be included in the EML. This awareness was observed in two hospitals (B and D). In both cases, however, special efforts to counter a possible 'no inclusion' decision were made by the manufacturers to empower the inclusion request. Interviewees mentioned these events. They were meant to convince larger numbers of health professionals within the institution and make way for the use and, lastly, inclusion of the drugs. This strategy is commonly used by the pharmaceutical industry (Angell, 2007).

The inability to manage effectively high-cost technologies in large institutions is similar to other cases studied in Brazil (Scheffer, 2008; Sancho, Vargens, 2009). Gertner (2010) followed up on the economic analyses performed by a company working for the pharmaceutical industry, showing that artificial demand was built for a new technology within the system, thus creating a market where there was none before. This situation is very distant from health priorities.

The Brazilian Network for Health Technology Assessment (HTA) - Rebrats $^{5}$ - seeks to stimulate HTA hubs in teaching hospitals, introducing the HTA culture and training human resources for the activity (Brasil, 2000, 2010; Getner, 2010 - include reference). During the selection process, DTCs should follow all important HTA criteria. However, the results from the DTCs in hospitals A, B, C and D show their inability to act as influential groups to prioritize and promote the discussion of HTA.

\section{CONCLUSIONS}

To deny the importance of DTCs for the Brazilian Health System is to disregard the fact that a cautious decision-making process is vital for efficacious, safe and cost-effective health care.

The interpretation of information obtained from in-depth interviews, the analysis of documents and direct observation techniques in four large complex university hospitals in Rio de Janeiro suggests that, even in those institutions that presented an operational DTC, the selection of medicines was inadequately performed. The results are most likely a consequence of a lack of organizational structure and of weak training of the members for the tasks involved. 
Efficacy, safety and cost were the principal criteria mentioned by the stakeholders involved in the process of medicines adoption in the hospitals. However, the analysis and interpretation of the results of this study indicate that decision-making is not, in fact, evidence-based and does not follow the above-mentioned criteria. Aspects such as the position or status of the health professional requesting inclusion of the medicine in the EML and industry influences may be contributing to the adoption of medicines. Moreover, the actual need for the technology appears to be viewed as less important.

University hospitals house an important array of new or highly complex technologies for SUS. This study contributed to the provision of relevant information about medicine selection in the state of Rio de Janeiro, especially of the process taking place in important teaching hospitals, which are trend-setters for the health system. While the results cannot be directly applied to other hospitals, we suggest that similar difficulties and barriers can be found in other facilities in the country.

Therefore, the selection process for new medicines performed in these hospitals must be carefully verified, and the flaws must be corrected. In the absence of the essential requirements for medicine selection long pointed out by the WHO, the first of which is the role of the DTC, the health system will remain hostage to the non-critical adoption of health technologies, strengthening the undue influence of the pharmaceutical industry, increasing health costs and producing risks for patients.

\section{REFERENCES}

ANGELL, M. A verdade sobre os laboratórios farmacêuticos. Ed. Record: São Paulo, 2007. 319 p.

ASSOCIAÇÃO BRASILEIRA DE HOSPITAIS UNIVERSITÁRIOS E DE ENSINO. ABRAHUE. Available at $<$ http: $/ /$ www.abrahue.org.br/ $>$. Accessed on 10 Dec., 2012.

AZEVEDO, C. S.; FERNANDES, M. I. A.; CARRETEIRO, T. C. Sob o domínio da urgência: a prática de diretores de hospitais públicos do Rio de Janeiro, Brasil. Cad. Saúde Pública, v.23, n.10, p.2410-2420, 2007.

BARDIN, L. Análise de conteúdo. Lisboa: Edições 70, 2002. $174 \mathrm{p}$.
BITTENCOURT, R. J.; HORTALE, V. A. A qualidade nos serviços de emergência de hospitais públicos e algumas considerações sobre a conjuntura recente no município do Rio de Janeiro. Ciên. Saúde Col., v.12, n.4, p.929-934, 2007.

BRASIL. Ministério da Saúde - Informes Técnicos Institucionais - Política Nacional de Medicamentos. Rev. Saúde Pública, v.34, n.2, p.206-209, 2000.

BRASIL. Ministério da Saúde. Cadastro nacional de estabelecimentos de saúde. Brasília: Ministério da Saúde, 2011. Available at: $<$ http://cnes.datasus.gov.br $>$. Accessed on: 2 Feb. 2011.

BRASIL. Ministério da Saúde. Política Nacional de Gestão de Tecnologias em Saúde / Ministério da Saúde, Secretaria de Ciência, Tecnologia e Insumos Estratégicos, Departamento de Ciência e Tecnologia. - Brasília: 2010. 48p. - (Série B. Textos Básicos em Saúde).

CECILIO, L. C. O. Autonomy versus worker's control: power management in the hospital. Ciênc. Saúde Col., v.4, n.2, p.315-329, 1999.

CHIEFFI, A. L.; BARATA, R. C. B. Ações judiciais: estratégia da indústria farmacêutica para introdução de novos medicamentos. Rev. Saúde Pública, v.44, n.3, p.421-9, 2010 .

GERTNER, A. Science of uncertainty: making cases for drug incorporation in Brazil. Anthropol. Quart., v. 83, n.1, p.97$122,2010$.

GUIMARÃES, J. A. A pesquisa médica e biomédica no Brasil. Comparações com o desempenho científico brasileiro e mundial. Ciênc. Saúde Col., v.9, n.2, p.303-327, 2004.

GUSTAFSSON, L. L.; WETTERMARK, B.; GODMAN, B.; ANDERSÉN-KARLSSON, E.; BERGMAN, U.; HASSELSTRÖM, J.; HENSJÖ, L. O.; HJEMDAHL, P.; JÄGRE, I.; JULANDER, M.; RINGERTZ, B.; SCHMIDT, D.; SJÖBERG, S.; SJÖQVIST, F.; STILLER, C. O.; TÖRNQVIST, E.; TRYSELIUS, R.; VITOLS, S.; VON BAHR, C. FOR REGIONAL DRUG EXPERT CONSORTIUM: The 'Wise List'- a comprehensive concept to select, communicate and achieve adherence to recommendations of essential drugs in ambulatory care in Stockholm. Basic Clin. Pharmacol. Toxicol., v.108, n.4, p.224-233, 2011. 
IBGE. INSTITUTO BRASILEIRO DE GEOGRAFIA E ESTATÍSTICA. 2012. Available at $<$ http://www.ibge.gov. br/home/>. Accessed on: 10 Dec. 2012.

LIMA-DELLAMORA, E. C.; CAETANO R.; GUSTAFSSON, L. L.; GODMAN, B. B.; PATTERSON, K.; OSORIODE-CASTRO, C. G. S. An analytical framework for assessing drug and therapeutics committee structure and work processes in tertiary Brazilian hospitals. Basic Clin. Pharmacol. Toxicol., v.115, n.3, 2014.

LIMA, E. C.; SANDES, V. S.; CAETANO, R.; OSORIO-DECASTRO, C. G. S. Incorporação e gasto com medicamentos de alta relevância financeira. Cad. Saúde Coletiva, v.18, n.4, p.551-559, 2010.

KRAUSS-SILVA, L. Avaliação tecnológica e análise custoefetividade em saúde: a incorporação de tecnologias e a produção de diretrizes clínicas para o SUS. Ciênc. Saúde Col., v.8, n.2, p.501-520, 2003.

MARINHO, A. Avaliação da eficiência técnica nos serviços de saúde nos municípios do Estado do Rio de Janeiro. Rev. Bras. Econ., v.57, n.3, p.515-534, 2003.

MARQUES, D. C.; ZUCCHI, P. Comissões farmacoterapêuticas no Brasil: aquém das diretrizes internacionais. Rev. Panam. Salud Publica, v.19, n.1, p.58-63, 2006.

MEDICI, A. C. University hospitals: past, present and future. Rev. Ass. Med. Brasil, v.47, n.2, p.149-156, 2001.

OSORIO-DE-CASTRO, C. G. S.; CASTILHO, S. R. (Orgs.). Diagnóstico da farmácia hospitalar no Brasil. Escola Nacional de Saúde Pública. Rio de Janeiro: Fundação Oswaldo Cruz, 2004. 150 p.

PALÁCIOS, M.; REGO, S.; LINO, M. H. Promoção e propaganda de medicamentos em ambientes de ensino: elementos para o debate. Interface (Botucatu), v.12, n.27, p.893-905, 2008.
PORTELA, M. C.; LIMA, S. M. L., BARBOSA, P. R.; VASCONCELOS, M. M.; UGÁ, M. A. D.; GERSCHMAN, S. Caracterização assistencial de hospitais filantrópicos no Brasil. Rev. Saúde Publica, v.36, n.6, p.811-818, 2004.

SANCHO, L. G.; VARGENS, J. M. C. Avaliação econômica em saúde na esfera de atenção local à saúde. Ciênc. Saúde Col., v.14, supl.1, p.1513-1521, 2009.

SANT'ANA, J. M. B.; PEPE, V. L. E.; FIGUEIREDO, T. A.; OSORIO-DE-CASTRO, C.G.S.; VENTURA, M. Rational therapeutics: health related elements in lawsuits demanding medicines. Rev. Saúde Pública, v.45, n.4, p.714-721, 2011.

SCHEFFER, M. C. Aids, tecnologia e acesso sustentável a medicamentos: a incorporação dos anti-retrovirais no Sistema Único de Saúde. São Paulo, 2008. [Thesis of Master Degree. Faculty of Medicine. University of São Paulo]. 238 p.

VEBER, A. P.; DIEHL, E; LEITE, S. N.; PROSPERO, E. N. S. Pharmaceutical assistance in local public health services in Santa Catarina (Brazil). Braz. J. Pharm. Sci., v.47, n.1, p.75-81, 2011.

WORLD HEALTH ORGANIZATION. WHO. Selección de medicamentos esenciales. In: Perspectivas politicas sobre medicamentos de la OMS. Ginebra, 2002. p.1-6.

WORLD HEALTH ORGANIZATION. WHO. Drug and therapeutics committees: a practical guide Department of Essential Drugs and Medicines Policy. Geneva; WHO, 2003. 146 p.

YIN, R. K. Estudo de caso: planejamento e métodos. Porto Alegre: Ed. Bookman, 2005. 270 p.

Received for publication on $23^{\text {rd }}$ September 2013 Accepted for publication on $03^{\text {rd }}$ April 2014 